\title{
Advanced glycation end products influence oral cancer cell survival via Bcl-xl and Nrf-2 regulation in vitro
}

\author{
SHUN-YAO KO ${ }^{1,2}$, HSHIN-AN KO ${ }^{3}$, TZONG-MING SHIEH ${ }^{4}$, TZONG-CHERNG CHI ${ }^{1,2}$, \\ HONG-I CHEN ${ }^{1,2}$, YI-TING CHEN ${ }^{5}$, YA-HUI YU ${ }^{5}$, SHU-HAN YANG ${ }^{5}$ and SHU-SHING CHANG ${ }^{2}$ \\ ${ }^{1}$ Graduate Institute of Medical Sciences, College of Health Science; ${ }^{2}$ Innovative Research Center of Medicine, \\ Chang Jung Christian University, Tainan $71101{ }^{3}$ Department of Food Science and Biotechnology, \\ National Chung Hsing University, Taichung 402; ${ }^{4}$ Department of Dental Hygiene, China Medical University, \\ Taichung 40402; ${ }^{5}$ Department of Bioscience Technology, Chang Jung Christian University, Tainan 71101, Taiwan, R.O.C.
}

Received August 24, 2015; Accepted January 6, 2017

DOI: $10.3892 / \mathrm{ol} .2017 .5809$

\begin{abstract}
An irreversible non-enzymatic reaction between carbohydrates and proteins results in the formation of advanced glycation end products (AGEs). AGEs have been demonstrated to be a risk factor of complications in patients with diabetes mellitus (DM). Previous studies have suggested that patients with DM exhibit a higher rate of metastasis of oral cancer and a lower cancer-associated survival rate. The receptor for AGEs (RAGE) has been associated with angiogenesis and an increase in cancer malignancy. Previous studies have suggested that AGE-RAGE regulates cell migration via extracellular signal-regulated kinase (ERK) phosphorylation. Nuclear factor-erythroid 2-related factor 2 (Nrf-2) is associated with the regulation of tumor protein p53 (p53) and the apoptotic response of oral cancer cells. AGEs are associated with oral cancer; however, the mechanism underlying this association remains to be elucidated. The present study hypothesized that AGEs regulate Nrf-2 and downstream pathways through ERK phosphorylation. The results of the current study demonstrated that AGEs inhibit the expression of Nrf-2, p53 and Bcl-2 associated $\mathrm{x}$ apoptosis regulator, and increase the expression of apoptosis regulator Bcl-x protein. The effect of AGEs was inhibited through the use of the PD98059. The present study demonstrated that AGEs regulate the downstream pathways $\mathrm{Nrf}-2$ and Bcl-xl via ERK phosphorylation. It is suggested that AGEs regulate the survival of oral cancer cells via Nrf-2 and
\end{abstract}

Correspondence to: Professor Shun-Yao Ko, Graduate Institute of Medical Sciences, College of Health Science, Chang Jung Christian University, 1 Changda Road, Gueiren, Tainan 71101, Taiwan, R.O.C. E-mail: syko@mail.cjcu.edu.tw

\section{Abbreviation: AGEs, advanced glycation end products}

Key words: advanced glycation end products, apoptosis regulator Bcl-x, extracellular signal-regulated kinase, phosphorylation, nuclear factor-erythroid 2-related factor 2, tumor protein p53
Bcl-xl through p53 regulation, which explains the poor prognosis of patients with DM who have oral cancer.

\section{Introduction}

An irreversible non-enzymatic reaction between carbohydrates and proteins produce advanced glycation end products (AGEs) $(1,2)$. The accumulation of AGEs increases with age $(3,4)$ and is typically higher in patients with diabetes mellitus (DM) (5). AGEs have been revealed to be a risk factor for complications of DM (6-9) and an important toxicity moiety for neuronal cells in Alzheimer's disease (10-13). Previous studies have demonstrated that cancer malignancy can be promoted by AGEs (14-16). Furthermore, the migration of oral cancer cells has been revealed to be increased by the receptor for AGEs (17). In a clinical setting, patients with DM exhibit a higher rate of metastasis of oral cancer and a lower cancer-associated survival rate (18). A strong association appears to exist between AGEs and oral cancer; however, the underlying mechanism of the involvement of AGEs in oral cancer remains to be elucidated.

Antioxidant responsive element is regulated by nuclear factor-erythroid 2-related factor 2 (Nrf-2), which in turn regulates the expression of antioxidant genes (19-22). Reactive oxygen species degradation $(23,24)$, anti-inflammatory responses (25-28), and neuroprotection (29) are regulated by Nrf-2 through the downstream antioxidant genes heme oxygenase $1(\mathrm{HO}-1)$ and $\mathrm{NAD}(\mathrm{P}) \mathrm{H}$ dehydrogenase quinone 1 (30-33). In addition, Nrf-2 regulates the apoptotic response via tumor protein p53 regulation (34). Furthermore, in oral cancer cells, Nrf-2 and HO-1 upregulation appear to be associated with apoptosis (35).

A previous study by our group demonstrated that AGEs regulate cell migration via extracellular signal-regulated kinase (ERK) phosphorylation (17). Therefore, it was hypothesized that AGEs regulate Nrf-2 and downstream signaling pathways through ERK phosphorylation. The expression of various apoptosis-associated proteins, including Nrf-2, HO-1, p53, Bcl-2 associated $\mathrm{x}$ apoptosis regulator (Bax) and apoptosis regulator $\mathrm{Bcl}-\mathrm{x}(\mathrm{Bcl}-\mathrm{xl})$, in SAS oral cancer cells following treatment with AGEs was analyzed through western 
blot analysis, in order to investigate the role and underlying mechanism of AGEs in oral cancer.

\section{Materials and methods}

Reagents. Phenylmethylsulfonyl fluoride, bovine serum albumin (BSA), DL-glyceraldehyde, resveratrol and PD98059 were purchased from Sigma-Aldrich (Merck Millipore, Darmstadt, Germany). Dulbecco's modified Eagle's medium (DMEM), fetal bovine serum (FBS), penicillin, streptomycin and Hank's Balanced Salt Solution were purchased from Invitrogen (Thermo Fisher Scientific, Inc., Waltham, MA, USA). GAPDH was purchased from Chemicon International, Inc. (Temecula, CA, USA). ERK, phosphorylated (p)-ERK, Nrf-2, HO-1, p53, Bax and Bcl-xl were purchased from Santa Cruz Biotechnology, Inc. (Dallas, TX, USA). Nitrocellulose membranes were purchased from Pall Corporation (Port Washington, NY, USA). The enhanced chemiluminescence (ECL) Immobilon western chemiluminescent HRP substrate kit was purchased from EMD Millipore (Billerica, MA, USA).

Preparation of AGEs. AGEs were prepared by incubation with BSA (pH 7.4) in PBS with $20 \mathrm{mM}$ DL-glyceraldehyde at $37^{\circ} \mathrm{C}$ for 1 week. The product was dialyzed using dialysis membranes (cat. no. MWCO 6000; Orange Scientific, Braine-l'Alleud, Belgium) in PBS at $4^{\circ} \mathrm{C}$ for $2 \mathrm{~h}$, and the cycle was repeated five times. The product was then concentrated at $4^{\circ} \mathrm{C}$ using Amicon Ultra-15 centrifugal filter units (EMD Millipore) and centrifuged at $830 \times \mathrm{g}$ for $30 \mathrm{~min}$ prior to storage at $-80^{\circ} \mathrm{C}$ as described in a previous study (36).

Cell culture and treatment. The oral cancer cell line SAS (Japanese Collection of Research Bioresources Cell Bank, Osaka, Japan) was cultured in an atmosphere of $5 \% \mathrm{CO}_{2}$ at $37^{\circ} \mathrm{C}$. The culture was maintained in DMEM (Invitrogen; Thermo Fisher Scientific, Inc.) supplemented with 10\% FBS, $100 \mathrm{U} / \mathrm{ml}$ penicillin, $2 \mathrm{mM}$ L-glutamine and $100 \mu \mathrm{g} / \mathrm{ml}$ streptomycin. Cells were cultured in serum-free DMEM for $24 \mathrm{~h}$ prior to treatment.

Western blot analysis. Total protein $(30 \mu \mathrm{g})$ was resolved using SDS-PAGE on a $10 \%$ gel and transferred to nitrocellulose membranes (Pall Corporation). The membranes were blocked using non-fat milk and incubated overnight at $4^{\circ} \mathrm{C}$ with primary antibodies directed against the following proteins: p-ERK, ERK, Nrf-2, HO-1, p53, Bax, Bcl-xl (all dilution, 1:1,000) and GAPDH (dilution, 1:40,000). Primary antibodies were removed and the membranes were washed using PBS with Tween-20 (PBST) buffer three times for $30 \mathrm{~min}$ at room temperature. The membranes were subsequently incubated for $45 \mathrm{~min}$ at room temperature with the following secondary antibodies: Horseradish peroxidase-conjugated anti-mouse (cat. no. AP124P; Chemicon International, Inc.), anti-rabbit (cat. no. AP132P; Merck Millipore) and anti-goat (cat. no. 605-4313; Rockland Immunochemicals Inc., Limerick, PA, USA) (all dilutions, 1:4,000). The secondary antibodies were removed and the membranes were washed using PBST buffer twice for $30 \mathrm{~min}$. Protein bands were detected using Millipore ECL. The density of the protein bands was quantified using Image $\mathrm{J}$ software version 1.4 (National Institutes of Health, Bethesda, MA, USA) following normalization with GAPDH. All data are presented as the mean \pm standard deviation from experiments performed in triplicate.

Statistical analysis. Student's t-tests were conducted using GraphPad Prism 5.0 software (GraphPad Software, Inc., La Jolla, CA, USA). P $<0.05$ was considered to indicate a statistically significant difference.

\section{Results}

Pathwaysassociated withapoptosis are regulated byresveratrol. SAS cells were treated with resveratrol $(1.25$ and $2.5 \mu \mathrm{M})$ for $24 \mathrm{~h}$, and Nrf-2, HO-1, p53 and Bax protein expression was detected using western blot analysis. The results demonstrated that, compared with the untreated control group, resveratrol significantly increased Nrf-2 $(1.25 \mu \mathrm{M}, 1.42 \pm 0.06, \mathrm{P}=0.002$; $2.5 \mu \mathrm{M}, 1.35 \pm 0.1, \mathrm{P}=0.03), \mathrm{HO}-1(1.25 \mu \mathrm{M}, 1.24 \pm 0.04, \mathrm{P}=0.003$; $2.5 \mu \mathrm{M}, 1.37 \pm 0.11, \mathrm{P}=0.03), \mathrm{p} 53(1.25 \mu \mathrm{M}, 1.32 \pm 0.1, \mathrm{P}=0.04$; $2.5 \mu \mathrm{M}, 1.79 \pm 0.24, \mathrm{P}=0.03)$ and $\operatorname{Bax}(2.5 \mu \mathrm{M}, 1.49 \pm 0.03$, $\mathrm{P}<0.0001$ ) expression (Fig. 1).

Regulation of apoptosis-associated pathways by AGEs. SAS cells were treated with AGEs (200 and $400 \mu \mathrm{g} / \mathrm{ml}$ ) or BSA (400 $\mu \mathrm{g} / \mathrm{ml}$; negative control) for $24 \mathrm{~h}$. Western blot analysis was used to detect Nrf-2, HO-1, p53 and Bax protein expression. The results revealed that compared with the untreated control group, treatment with $400 \mu \mathrm{g} / \mathrm{ml}$ AGEs significantly decreased Nrf-2 (0.64 $\pm 0.05 ; P=0.002)$, p53 (0.72 \pm 0.06 ; $\mathrm{P}=0.008)$ and $\mathrm{Bax}(0.7 \pm 0.03 ; \mathrm{P}=0.0005)$ expression (Fig. 2).

AGEs regulation of apoptosis-associated signaling pathways via ERK phosphorylation. Following the treatment of SAS cells with AGEs or BSA for $24 \mathrm{~h}, \mathrm{Bcl}-\mathrm{xl}$ and p-ERK were detected using western blot analysis. Treatment with AGEs was associated with a significant increase in Bcl-xl $(200 \mu \mathrm{g} / \mathrm{ml}$, $1.23 \pm 0.07, \mathrm{P}=0.03 ; 400 \mu \mathrm{g} / \mathrm{ml}, 1.36 \pm 0.04 ; \mathrm{P}=0.0006$; Fig. $3 \mathrm{~A})$ and ERK phosphorylation $(200 \mu \mathrm{g} / \mathrm{ml}, 1.2 \pm 0.01, \mathrm{P}<0.00001$; $400 \mu \mathrm{g} / \mathrm{ml}, 1.26 \pm 0.02, \mathrm{P}=0.0004$; Fig. 3B) compared with the untreated control groups. However, treatment with $400 \mu \mathrm{g} / \mathrm{ml}$ BSA also significantly increased p-ERK compared with the control group $(1.25 \pm 0.04$; $\mathrm{P}=0.003$; Fig. $3 \mathrm{~B})$. A pretreatment of $10 \mu \mathrm{M}$ PD98059 for $1 \mathrm{~h}$ was used on the cells to inhibit the phosphorylation of ERK (Fig. 4A). Pretreatment with PD98059 blocked the effect of AGEs on HO-1, Bcl-xl and Bax expression (Fig. 4B). Furthermore, compared with the untreated control group, pretreatment with PD98059 prior to treatment with AGEs significantly increased the expression of Nrf-2 $(200 \mu \mathrm{g} / \mathrm{ml}, 1.27 \pm 0.04, \mathrm{P}=0.003 ; 400 \mu \mathrm{g} / \mathrm{ml}, 1.24 \pm 0.03$, $\mathrm{P}=0.001)$ and $\mathrm{p} 53(200 \mu \mathrm{g} / \mathrm{ml}, 1.43 \pm 0.06, \mathrm{P}=0.002 ; 400 \mu \mathrm{g} / \mathrm{ml}$, $1.39 \pm 0.08, \mathrm{P}=0.01$ ) (Fig. 4B). The mechanism by which AGEs were observed to influence the survival rate of oral cancer cells in the present study is presented in Fig. 5.

\section{Discussion}

An association has been demonstrated between oral cancer and DM (37-39); however, the mechanism underlying this 


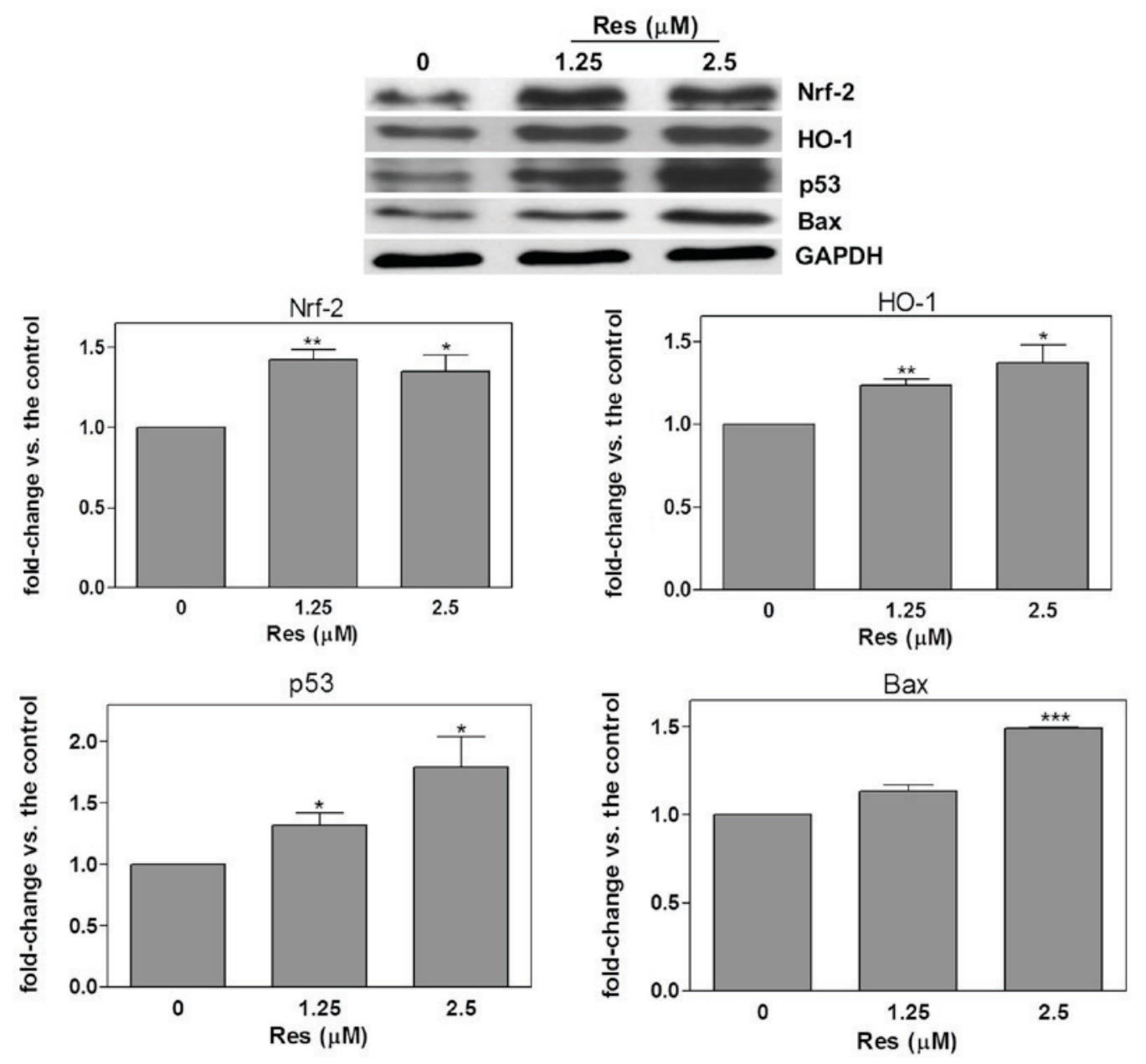

Figure 1. Regulation of apoptosis-associated signaling pathways by resveratrol. SAS cells were treated with resveratrol (1.25 and $2.5 \mu \mathrm{M})$ for $24 \mathrm{~h}$. Nrf-2, HO-1, p53 and Bax were subsequently detected by western blot analysis. Resveratrol resulted in a significant increase in the expression level of Nrf-2, HO-1, p53 and Bax compared with the untreated control group. Results are presented as the mean \pm standard deviation. ${ }^{*} \mathrm{P}<0.05 ;{ }^{* * *} \mathrm{P}<0.001 ;{ }^{* * *} \mathrm{P}<0.0001$ all in comparison to the control. Nrf-2, nuclear factor-erythroid 2-related factor 2; p53, tumor protein p53; HO-1, heme oxygenase 1; Bax, Bcl-2 associated x apoptosis regulator; Res, resveratrol.

association remains to be elucidated. A previous study by our group revealed that AGEs regulate oral cancer cell migration via the ERK signaling pathway (17). The results demonstrated the mechanism by which AGEs regulate p53 via ERK and downstream Nrf-2 and Bcl-xl. To the best of our knowledge, this is the first study to elucidate the mechanism of action of AGEs in oral cancer cells.

Previous studies have demonstrated the antitumorigenic effects of resveratrol (40-42). In oral cancer, resveratrol suppresses cell growth, DNA synthesis, migration and invasion, and increases cell apoptosis (43-45). A previous study reported that Nrf-2 regulates the p53 signaling pathway, leading to an apoptotic response (34). A study by Lee et al (35) suggested that the apoptosis of oral cancer cells is regulated by Nrf-2 and downstream HO-1 and p53. These results support the contention that Nrf-2 enhances cell apoptosis via the p53 signaling pathway. The results of the present study demonstrated that resveratrol significantly increased Nrf-2, HO-1, p53 and Bax protein expression, suggesting that resveratrol induces apoptosis through $\mathrm{Nrf-2}$, HO-1, p53 and Bax signaling pathways. The results of the current study demonstrated that, in contrast to resveratrol, AGEs significantly decrease Nrf-2, HO-1, p53 and Bax, and increase Bcl-xl protein expression. This indicates that AGEs modulate oral cancer survival via regulation of the expression of Nrf-2 and Bcl-xl.

In the present study, ERK phosphorylation was significantly upregulated by AGEs and the pretreatment of SAS cells with PD98059 to suppress ERK activation inhibited the effects of AGEs on p-ERK, HO-1, Bcl-xl and Bax expression, whereas $\mathrm{Nrf}-2$ and p53 expression significantly increased. Treatment with AGEs significantly increased Bcl-xl, and decreased p53 protein expression. A previous study by Chipuk et al (46) suggested that an interaction between Bcl-xl and p53 inhibits the activation of Bax. Li et al (47) reported that Bcl-xl inhibits p53 resulting in an anti-apoptotic effect. These results suggest that AGEs regulate $\mathrm{p} 53$ via ERK phosphorylation to inhibit $\mathrm{Nrf}-2$ and activate Bcl-xl. In addition, AGEs and BSA increased ERK phosphorylation in the current study. However, AGEs decreased Nrf-2 and p53 protein expression. The pretreatment of SAS cells with PD98059 increased Nrf-2 and p53 expression. The results of the present study suggest that treatment with AGEs or BSA differ regarding their effects on oral cancer cells (17).

The results of the current study suggest that AGEs decrease $\mathrm{Nrf}-2$ and p53 expression and increase Bcl-xl expression via 

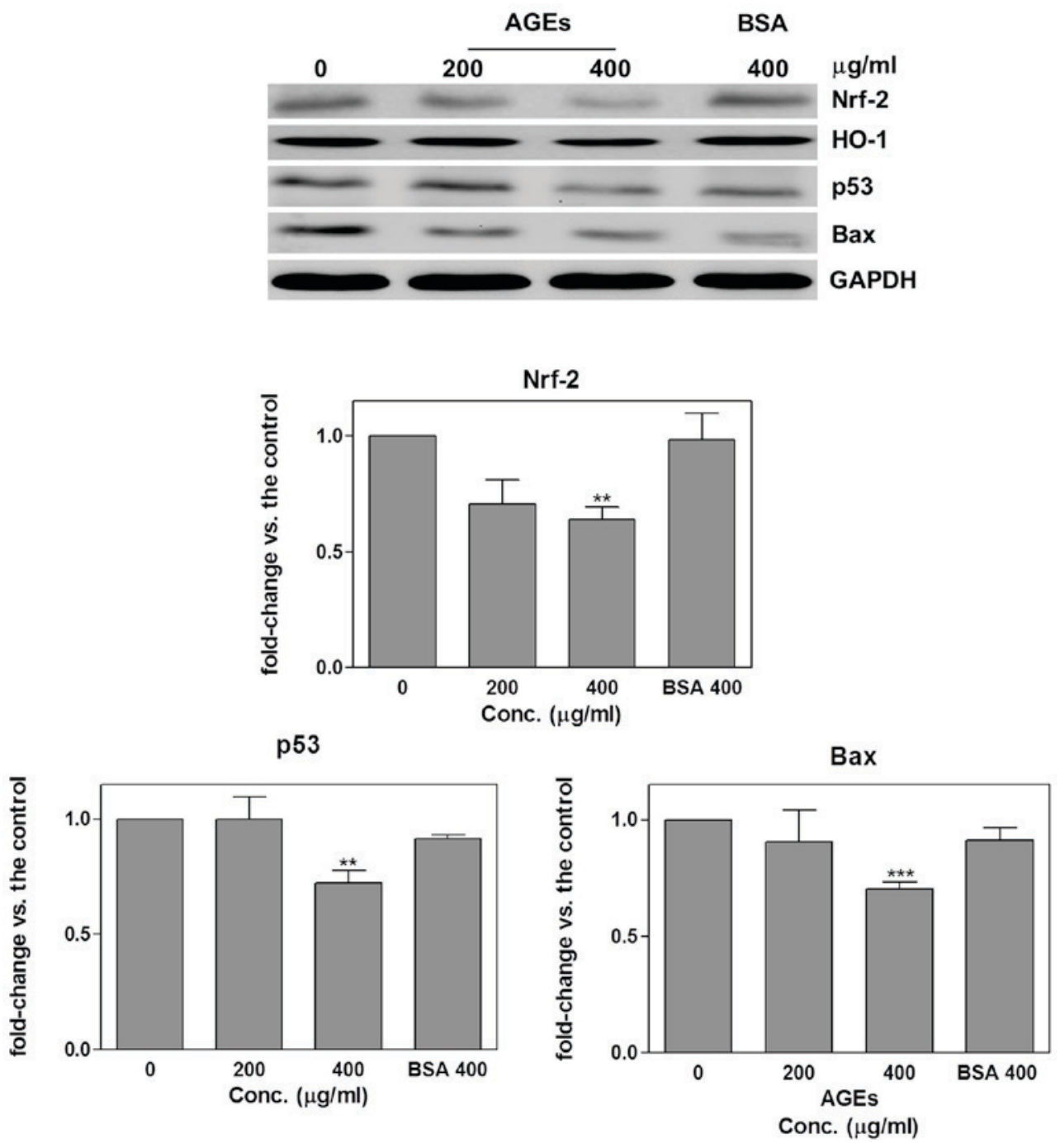

Figure 2. Regulation of apoptosis-associated pathways by AGEs. SAS cells were treated with AGEs (200 and $400 \mu \mathrm{g} / \mathrm{ml})$ or BSA ( $400 \mu \mathrm{g} / \mathrm{ml}$; negative control) for $24 \mathrm{~h}$. Western blot analysis was then performed to detect Nrf-2, HO-1, p53 and Bax protein expression. Treatment with AGEs resulted in a significant decrease in Nrf-2, p53 and Bax expression compared with the untreated control group. Results are presented as the mean \pm standard deviation. ${ }^{* *} \mathrm{P}<0.001$; ${ }^{* * *} \mathrm{P}<0.0001$ all in comparison to the control. AGEs, advanced glycation end products; BSA, bovine serum albumin; Nrf-2, nuclear factor-erythroid 2-related factor 2; p53, tumor protein p53; HO-1, heme oxygenase 1; Bax, Bcl-2 associated x apoptosis regulator; Res, resveratrol; conc., concentration.
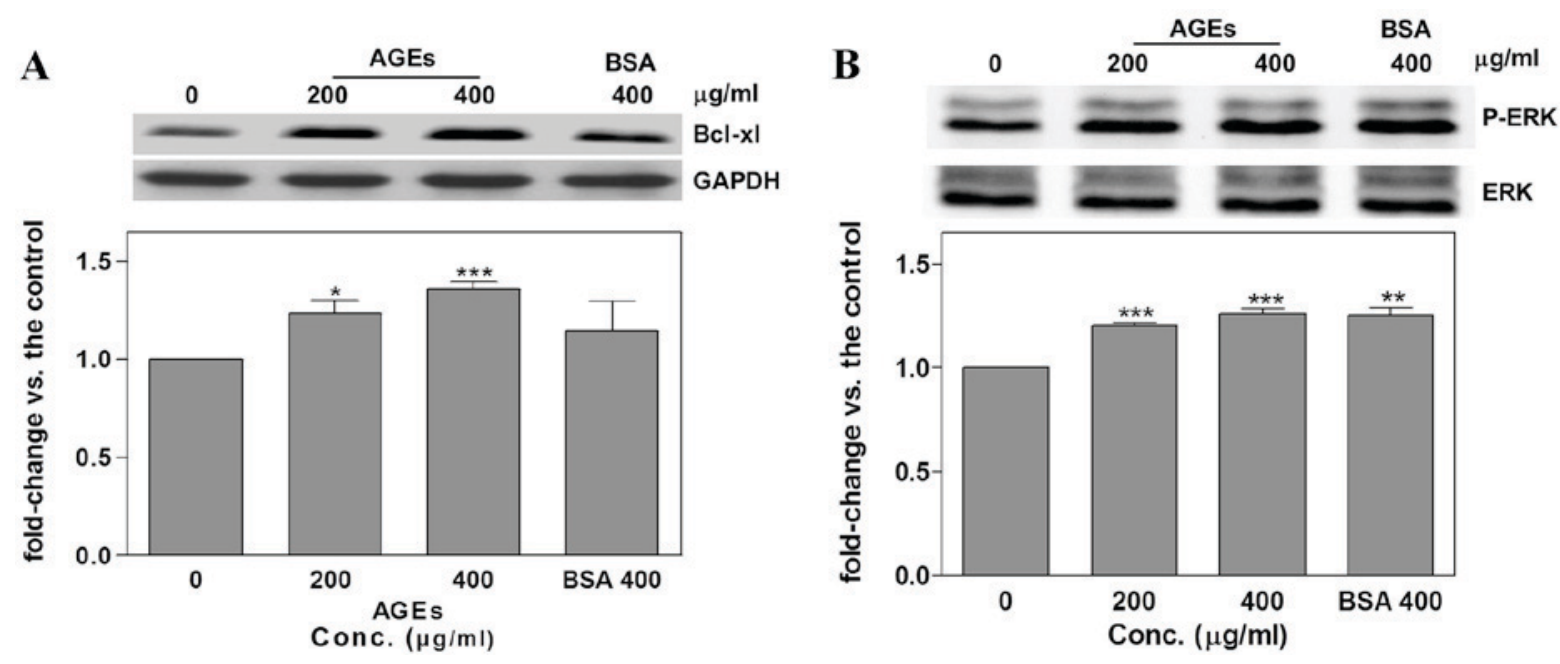

Figure 3. Regulation of Bcl-xl and p-ERK expression by AGEs. SAS cells were treated with AGEs or BSA for 24 h. Bcl-xl and p-ERK were detected using western blot analysis. These results demonstrated that treatment with AGEs significantly increased (A) Bcl-xl and (B) p-ERK expression compared with the untreated control group. Results are presented as the mean \pm standard deviation. ${ }^{*} \mathrm{P}<0.05 ;{ }^{* *} \mathrm{P}<0.001 ;{ }^{* * *} \mathrm{P}<0.0001$ all in comparison to the control. AGEs, advanced glycation end products; BSA, bovine serum albumin; Bcl-xl, apoptosis regulator Bcl-x; ERK, extracellular signal-regulated kinase; p-, phosphorylated; Res, resveratrol; conc., concentration. 

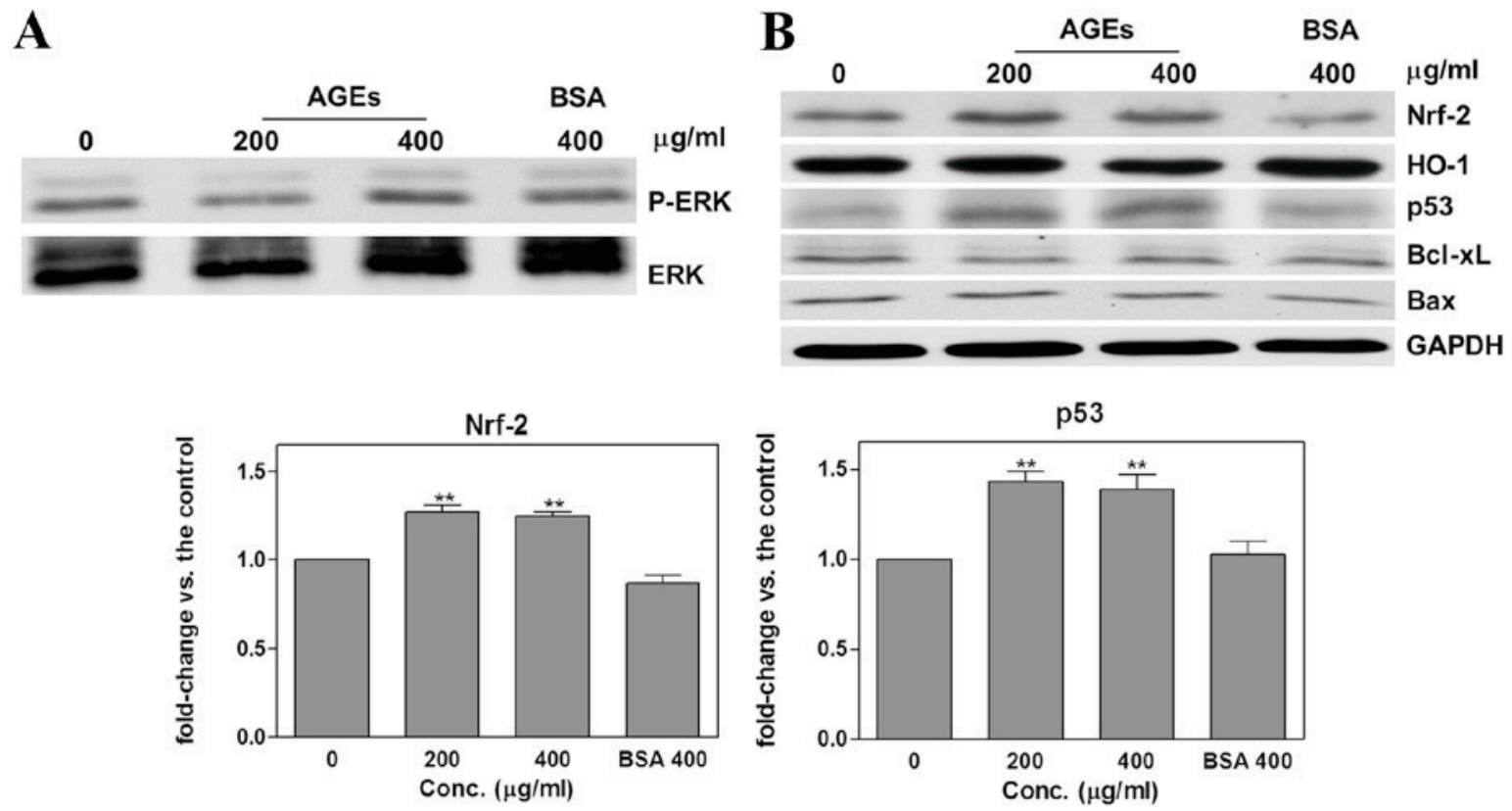

Figure 4. Effects of AGEs following PD98059 pretreatment. Pretreating cells with $10 \mu \mathrm{M}$ PD98059 for $1 \mathrm{~h}$ resulted in (A) a reduction in the expression of p-ERK and (B) inhibition of the effects of AGEs on HO-1, Bcl-xl and Bax expression, and significant increase in Nrf- 2 and p53 expression compared with the untreated control group. Results are presented as the mean \pm standard deviation. ${ }^{* *} \mathrm{P}<0.001$ all in comparison to control. AGEs, advanced glycation end products; Bcl-xl, apoptosis regulator Bcl-x; Nrf-2, nuclear factor-erythroid 2-related factor 2; p53, tumor protein p53; HO-1, heme oxygenase 1; Bax, Bcl-2 associated x apoptosis regulator; ERK, extracellular signal-regulated kinase; p-, phosphorylated; Res, resveratrol; conc., concentration.

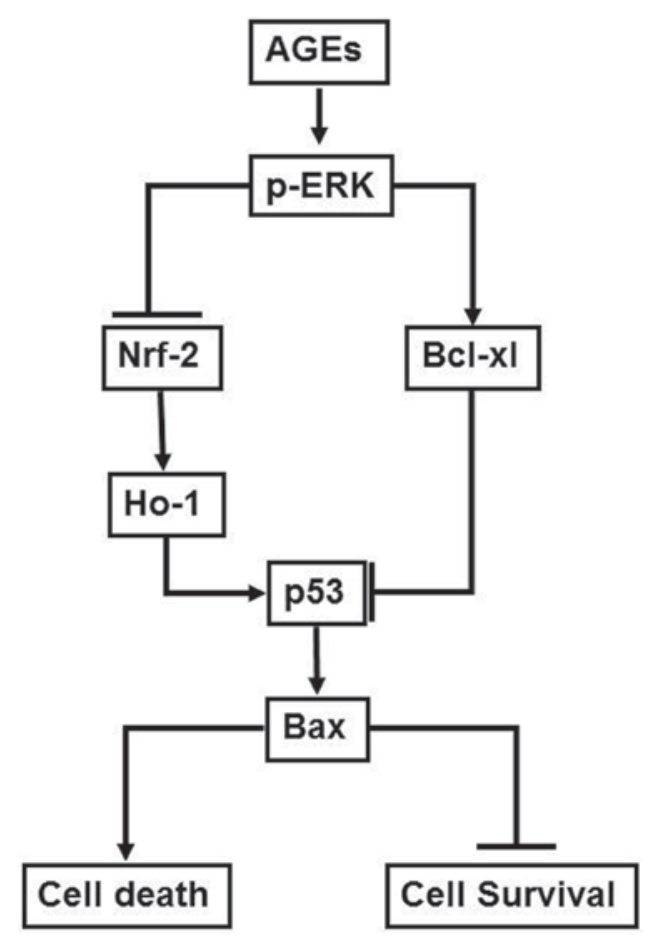

Figure 5. AGEs influence signaling pathways associated with oral cancer cell survival. AGEs increase ERK phosphorylation, which stimulates downstream Nrf-2 inhibition and Bcl-xl upregulation. This subsequently suppresses p53 and Bax expression, which manifests as a change in the survival rate of oral cancer cells. AGEs, advanced glycation end products; Bcl-xl, apoptosis regulator Bcl-x; Nrf-2, nuclear factor-erythroid 2-related factor 2; p53, tumor protein p53; HO-1, heme oxygenase 1; Bax, Bcl-2 associated $\mathrm{x}$ apoptosis regulator; p-ERK, phosphorylated-extracellular signal-regulated kinase.

ERK phosphorylation. To the best of our knowledge, this is the first study to demonstrate that AGEs regulate the expression of Nrf-2 and Bcl-xl, which subsequently influences p53 expression via ERK phosphorylation. In conclusion, the results of the present study suggest a mechanism by which AGEs influence the survival rate of oral cancer cells. This mechanism involves AGEs increasing ERK phosphorylation, which stimulates downstream Nrf-2 inhibition and Bcl-xl upregulation. This subsequently suppresses $\mathrm{p} 53$ and Bax expression, the effects of which manifest as a change in the survival rate of oral 
cancer cells. These findings explain the increase in oral cancer invasiveness and decrease in the survival rate of patients with DM, who typically have higher levels of AGEs. In addition, the results of the current study indicate that the accumulation of AGEs due to aging or DM promotes the progression of oral cancer.

\section{Acknowledgements}

The present study was supported by the National Science Council of Taiwan (grant no. 100-2314-B-309-002-MY3).

\section{References}

1. Kasper M and Funk RH: Age-related changes in cells and tissues due to advanced glycation end products (AGEs). Arch Gerontol Geriatr 32: 233-243, 2001.

2. Ramasamy R, Vannucci SJ, Yan SS, Herold K, Yan SF and Schmidt AM: Advanced glycation end products and RAGE: A common thread in aging, diabetes, neurodegeneration, and inflammation. Glycobiology 15: 16R-28R, 2005.

3. Luth HJ, Ogunlade V, Kuhla B, Kientsch-Engel R, Stahl P, Webster J, Arendt T and Münch G: Age- and stage-dependent accumulation of advanced glycation end products in intracellular deposits in normal and Alzheimer's disease brains. Cereb Cortex 15: 211-220, 2005

4. Munch G, Thome J, Foley P, Schinzel R and Riederer P: Advanced glycation endproducts in ageing and Alzheimer's disease. Brain Res Brain Res Rev 23: 134-143, 1997.

5. Thorpe SR and Baynes JW: Role of the Maillard reaction in diabetes mellitus and diseases of aging. Drugs Aging 9: 69-77, 1996.

6. Schmidt AM, Yan SD, Yan SF and Stern DM: The biology of the receptor for advanced glycation end products and its ligands. Biochim Biophys Acta 1498: 99-111, 2000.

7. Sato T, Iwaki M, Shimogaito N, Wu X, Yamagishi S and Takeuchi M: TAGE (toxic AGEs) theory in diabetic complications. Curr Mol Med 6: 351-358, 2006.

8. Basta G, Schmidt AM and De Caterina R: Advanced glycation end products and vascular inflammation: Implications for accelerated atherosclerosis in diabetes. Cardiovasc Res 63: 582-592, 2004.

9. Thornalley PJ: Glycation free adduct accumulation in renal disease: The new AGE. Pediatr Nephrol 20: 1515-1522, 2005.

10. Takeuchi M, Kikuchi S, Sasaki N, Suzuki T, Watai T, Iwaki M, Bucala R and Yamagishi S: Involvement of advanced glycation end-products (AGEs) in Alzheimer's disease. Curr Alzheimer Res 1: 39-46, 2004.

11. Sato T, Shimogaito N, Wu X, Kikuchi S, Yamagishi S and Takeuchi M: Toxic advanced glycation end products (TAGE) theory in Alzheimer's disease. Am J Alzheimers Dis Other Demen 21: 197-208, 2006.

12. Takeuchi M, Bucala R, Suzuki T, Ohkubo T, Yamazaki M, Koike T, Kameda Y and Makita Z: Neurotoxicity of advanced glycation end-products for cultured cortical neurons. J Neuropathol Exp Neurol 59: 1094-1105, 2000.

13. Choei H, Sasaki N, Takeuchi M, Yoshida T, Ukai W, Yamagishi S, Kikuchi S and Saito T: Glyceraldehyde-derived advanced glycation end products in Alzheimer's disease. Acta Neuropathol 108: 189-193, 2004

14. Bhawal UK, Ozaki Y, Nishimura M, Sugiyama M, Sasahira T, Nomura Y, Sato F, Fujimoto K, Sasaki N, Ikeda MA, et al: Association of expression of receptor for advanced glycation end products and invasive activity of oral squamous cell carcinoma. Oncology 69: 246-255, 2005.

15. Cai Q, Li BY, Gao HQ, Zhang JH, Wang JF, Yu F, Yin M and Zhang Z: Grape seed procyanidin b2 inhibits human aortic smooth muscle cell proliferation and migration induced by advanced glycation end products. Biosci Biotechnol Biochem 75: 1692-1697, 2011

16. Takino J, Yamagishi S and Takeuchi M: Cancer malignancy is enhanced by glyceraldehyde-derived advanced glycation end-products. J Oncol 2010: 739852, 2010.

17. Ko SY, Ko HA, Shieh TM, Chang WC, Chen HI, Chang SS and Lin IH: Cell migration is regulated by AGE-RAGE interaction in human oral cancer cells in vitro. PLoS One 9: e110542, 2014.
18. Wu CH, Wu TY, Li CC, Lui MT, Chang KW and Kao SY: Impact of diabetes mellitus on the prognosis of patients with oral squamous cell carcinoma: A retrospective cohort study. Ann Surg Oncol 17: 2175-2183, 2010.

19. Motohashi H, Katsuoka F, Engel JD and Yamamoto M: Small Maf proteins serve as transcriptional cofactors for keratinocyte differentiation in the Keap1-Nrf2 regulatory pathway. Proc Natl Acad Sci USA 101: 6379-6384, 2004.

20. Ishii T, Itoh K, Takahashi S, Sato H, Yanagawa T, Katoh Y, Bannai S and Yamamoto M: Transcription factor Nrf2 coordinately regulates a group of oxidative stress-inducible genes in macrophages. J Biol Chem 275: 16023-16029, 2000.

21. Ishii T, Itoh $\mathrm{K}$ and Yamamoto M: Roles of Nrf2 in activation of antioxidant enzyme genes via antioxidant responsive elements. Methods Enzymol 348: 182-190, 2002.

22. Itoh K, Chiba T, Takahashi S, Ishii T, Igarashi K, Katoh Y, Oyake T, Hayashi N, Satoh K, Hatayama I, et al: An Nrf2/small Maf heterodimer mediates the induction of phase II detoxifying enzyme genes through antioxidant response elements. Biochem Biophys Res Commun 236: 313-322, 1997.

23. Hsieh CY, Hsiao HY, Wu WY, Liu CA, Tsai YC, Chao YJ, Wang DL and Hsieh HJ: Regulation of shear-induced nuclear translocation of the Nrf2 transcription factor in endothelial cells. J Biomed Sci 16: 12, 2009.

24. Mann GE, Rowlands DJ, Li FY, de Winter P and Siow RC: Activation of endothelial nitric oxide synthase by dietary isoflavones: Role of NO in Nrf2-mediated antioxidant gene expression. Cardiovasc Res 75: 261-274, 2007

25. Itoh K, Mochizuki M, Ishii Y, Ishii T, Shibata T, Kawamoto Y, Kelly V, Sekizawa K, Uchida K and Yamamoto M: Transcription factor Nrf2 regulates inflammation by mediating the effect of 15-deoxy-Delta $(12,14)$-prostaglandin j(2). Mol Cell Biol 24: 36-45, 2004.

26. Chen XL, Dodd G, Thomas S, Zhang X, Wasserman MA, Rovin BH and Kunsch C: Activation of Nrf2/ARE pathway protects endothelial cells from oxidant injury and inhibits inflammatory gene expression. Am J Physiol Heart Circ Physiol 290: H1862-H1870, 2006.

27. Mochizuki M, Ishii Y, Itoh K, Iizuka T, Morishima Y, Kimura T, Kiwamoto T, Matsuno Y, Hegab AE, Nomura A, et al: Role of 15-deoxy delta(12,14) prostaglandin J2 and Nrf2 pathways in protection against acute lung injury. Am J Respir Crit Care Med 171: 1260-1266, 2005

28. Harada N, Kanayama M, Maruyama A, Yoshida A, Tazumi K, Hosoya T, Mimura J, Toki T, Maher JM, Yamamoto M and Itoh K: Nrf2 regulates ferroportin 1-mediated iron efflux and counteracts lipopolysaccharide-induced ferroportin $1 \mathrm{mRNA}$ suppression in macrophages. Arch Biochem Biophys 508: 101-109, 2011.

29. Bell KF, Al-Mubarak B, Fowler JH, Baxter PS, Gupta K, Tsujita T, Chowdhry S, Patani R, Chandran S, Horsburgh K, et al: Mild oxidative stress activates Nrf2 in astrocytes, which contributes to neuroprotective ischemic preconditioning. Proc Natl Acad Sci USA 108: E1-E2; author reply E3-4, 2011.

30. Riley RJ and Workman P: DT-diaphorase and cancer chemotherapy. Biochem Pharmacol 43: 1657-1669, 1992.

31. Clark JE, Foresti R, Green CJ and Motterlini R: Dynamics of haem oxygenase- 1 expression and bilirubin production in cellular protection against oxidative stress. Biochem J $348 \mathrm{Pt} 3$ : 615-619, 2000

32. Jyrkkanen HK, Kansanen E, Inkala M, Kivelä AM, Hurttila H, Heinonen SE, Goldsteins G, Jauhiainen S, Tiainen S, Makkonen $\mathrm{H}$, et al: $\mathrm{Nrf} 2$ regulates antioxidant gene expression evoked by oxidized phospholipids in endothelial cells and murine arteries in vivo. Circ Res 103: e1-e9, 2008.

33. Nioi P, McMahon M, Itoh K, Yamamoto M and Hayes JD: Identification of a novel Nrf2-regulated antioxidant response element (ARE) in the mouse NAD(P)H: Quinone oxidoreductase 1 gene: Reassessment of the ARE consensus sequence. Biochem J 374: 337-348, 2003.

34. You A, Nam CW, Wakabayashi N, Yamamoto M, Kensler TW and Kwak MK: Transcription factor Nrf2 maintains the basal expression of Mdm2: An implication of the regulation of p53 signaling by Nrf2. Arch Biochem Biophys 507: 356-364, 2011.

35. Lee YM, Auh QS, Lee DW, Kim JY, Jung HJ, Lee SH and Kim EC: Involvement of Nrf2-mediated upregulation of heme oxygenase-1 in mollugin-induced growth inhibition and apoptosis in human oral cancer cells. Biomed Res Int 2013: 210604, 2013. 
36. Ko SY, Lin YP, Lin YS and Chang SS: Advanced glycation end products enhance amyloid precursor protein expression by inducing reactive oxygen species. Free Radic Biol Med 49: 474-480, 2010.

37. Vairaktaris E, Spyridonidou S, Goutzanis L, Vylliotis A, Lazaris A Donta I, Perrea D, Yapijakis C and Patsouris E: Diabetes and oral oncogenesis. Anticancer Res 27: 4185-4193, 2007.

38. Girtan M, Zurac S, Stăniceanu F, Bastian A, Popp C, Nichita L, Laba E and Forna N: Oral epithelial hyperplasia in diabetes mellitus. Rom J Intern Med 47: 201-203, 2009.

39. Vairaktaris E, Kalokerinos G, Goutzanis L, Yapijakis C, Derka S, Vassiliou S, Spyridonidou S, Vylliotis A, Nkenke E, Lazaris A and Patsouris E: Diabetes enhances cell proliferation but not $\mathrm{Bax} / \mathrm{Bcl}-2$-mediated apoptosis during oral oncogenesis. Int J Oral Maxillofac Surg 37: 60-65, 2008.

40. Ulrich S, Loitsch SM, Rau O, von Knethen A, Brüne B, Schubert-Zsilavecz M and Stein JM: Peroxisome proliferator-activated receptor gamma as a molecular target of reveratrol-induced modulation of polyamine metabolism. Cancer Res 66: 7348-7354, 2006

41. Frazzi R, Valli R, Tamagnini I, Casali B, Latruffe N and Merli F: Resveratrolmediated apoptosis of hodgkin lymphoma cells invovles SIRT1 inhibition and FOXO3a hyperacetylation. Int J Cancer 132: 1013-1021, 2013.
42. Yang Q, Wang B, Zang W, Wang X, Liu Z, Li W and Jia J: Resveratrol inhibits the growth of gastric cancer by inducing G1 phase arrest and senescence in a Sirt1-dependent manner. PLoS One 8: e70627, 2013

43. Elattar TM and Virji AS: The effect of red wine and its components on growth and proliferation of human oral squamous carcinoma cells. Anticancer Res 19: 5407-5414, 1999.

44. Shan Z, Yang G, Xiang W, Pei-jun W and Bin Z: Effects of resveratrol on oral squamous cell carcinoma (OSCC) cells in vitro. J Cancer Res Clin Oncol 140: 371-374, 2014.

45. Kim SH, Kim HJ, Lee MH, Yu SK, Kim CS, Kook JK, Chun HS, Park E, Lee SY, Kim SG, et al: Resveratrol induces apoptosis of KB human oral cancer cells. J Korean Soc Appl Biol Chem 54: 966-971, 2011.

46. Chipuk JE, Kuwana T, Bouchier-Hayes L, Droin NM, Newmeyer DD, Schuler M and Green DR: Direct activation of Bax by p53 mediates mitochondrial membrane permeabilization and apoptosis. Science 303: 1010-1014, 2004

47. Li G, Xie N, Yao Y, Zhang Y, Guo J, Feng Y, Lv F, Xiao RP and Cao CM: Identification of PI3K regulatory subunit $\mathrm{p} 55 \gamma$ as a novel inhibitor of vascular smooth muscle cell proliferation and neointimal formation. Cardiovasc Res 105: 75-85, 2014. 